\title{
Analysis on the Educational Service Quality of Private Colleges and Universities in Xi'an*
}

\author{
Yanqing Zeng \\ Xi'an FanYi University \\ Xi'an, China 710105
}

\begin{abstract}
Establishing the quality measurement tools of college education services is of great significance to the development of colleges and universities. This study takes private colleges and universities of $\mathrm{Xi}^{\prime}$ an as the research objects, establishes relevant service quality measurement tools and analyzes it. In addition, the research also explains the problems in the education services quality of colleges and puts forward corresponding suggestions.
\end{abstract}

Keywords-Xi'an private colleges; education service quality; measurement

\section{INTRODUCTION}

With the advent of the era of popularization of higher education, education fees have become an inevitable trend. Private college is a typical model of paid education. As consumers, students have the right to judge the quality of the products they consume. Therefore, the subject that evaluates the quality of higher education services should not only be the education manager or implementer, but also include evaluation from the level of student. Although private colleges in Xi'an have a certain history of development, they are still in the initial stage of development with imperfect system and uneven education quality. Therefore, how to attract students by their own educational service quality, brand and reputation is the issue that private colleges should consider in terms of sustainable development. Only by continuously improving the quality of educational services in education, teaching and management and making students maintain a high degree of satisfaction, can they create a good image of the school in the society and improve the economic and social benefits of running a school.

\section{THE THEORETICAL BASIS OF EDUCATIONAL SERVICE QUALITY}

\section{A. The Connotation of Educational Services Quality}

Paying attention to the educational services quality has always been the focus of development highlighted by China

*This paper is the phased research result of the project of Shaanxi Provincial Department of Education: "Empirical Research on the Educational Service Quality of the Three Private Colleges and Universities in Xi'an" (Project No. 17JK0985).

This paper is the phased research result of the Shaanxi Provincial Social Science Fund Project "Research on Humanistic Care and Psychological Coordination in Ideological and Political Education for College Students in Shaanxi Province" (Project No. 2014M04). on the road to recovery. Since the founding of the People's Republic of China, the leaders of the Party and state have fully realized the importance of education for the development of individuals, regions and countries. At the 19th National People's Congress in China, the Party has launched a new discussion on developing education and improving the quality of education. It can be seen that the educational services quality has a very important position in the development of China. The core of educational service is to improve the level of education, enhance students' ability, and provide useful talents for the society.

\section{B. Overview of Research on Education Service Quality}

Many people have started research on the issue of educational service quality. For example, Aristotle of the West and the leader of communism Marx have all discussed it. For instance, Marx believes that education needs to make comprehensive exploitation of a person's multifaceted capabilities. And people's outlook can't be separated from the era in which they live. Both Aristotle and Marx have their own limitations in understanding the quality of educational services. Therefore, with the constant changes in society, many Chinese and Western researchers are still engaged in the study of educational services quality. For example, the educational researcher $\mathrm{A} \bullet$ Parasuraman et al. proposed the SERVQUAL model in 1988. Until today, the SERVQUAL model has been widely used in the study of educational service quality. It is precisely because of this group of researchers that people's understanding of the educational service quality has become more and more profound, and the theory related to the educational services quality has been more and more perfect.

\section{Research on the Relationship Between Educational Service Quality and Students}

Through the analysis of the relevant research on the educational services quality and the investigation of the actual situation, the author finds that the quality of educational services has an impact on students. This influence is manifested in such places: First, the educational service quality affects the development of students' comprehensive capacity. Second, the education service quality affects the employment of students. Third, the educational service quality has a certain degree of connection with the satisfaction of students in school. Fourth, the quality 
of educational services is linked to the subjective initiative of students.

\section{Gap Model of Education Service Quality}

The gap model service quality was a theoretical model proposed by American marketing experts Valarie AZeithamal, A. Parasuraman, and Leonard L. Berry in the 1980s and 1990s. The gap model of service quality has also become a 5GAP model. The gap model of educational service quality refers to the application of this model in the educational service quality, which can analyze the root causes of problems in educational service quality. In the model of educational service quality, students are the key to the problem, and the gap between students' expectations of teaching and the students' perception of teaching is the most important. The analysis of the gap model of teaching service quality has the important significance of knowing the shortcomings in the teaching process and improving it, and shortening the gap between teaching and student expectations.

\section{ESTABLISHMENT OF EDUCATIONAL SERVICE QUALITY MODEL FOR PRIVATE COLLEGES AND UNIVERSITIES AND MEASUREMENT TOOLS}

\section{A. Model/Tools/Operations on Variables}

1) Proposal of model: This study analyzes the educational service quality in private universities. Therefore, establishing a relevant model is the first step in solving the problem. The process of establishing a model in this study can be divided into the following stages: First, the corresponding theory is studied. The theory of the educational service quality model is based on the SERVQUAL model proposed by $A \cdot$ Parasuraman et al. in 1988, which combines the research of the educational service quality by researchers at home and abroad. Second, the initial model is established. The theoretical knowledge of the model obtained above is still relatively abstract and needs to be transformed into a model that can be applied practically. In the process of transformation, this study combines the actual characteristics of the research object, and achieves the refinement and localization of the model. Third, the model is perfected. After establishing the relevant model, there may be some errors or unreasonable places. In response to this situation, this study makes modification and processing. The specific modification methods are as follows: Consulting the relevant personnel's opinions on the model, and making targeted modifications based on the feedback.

After the above three steps, the model variables determined by this study include the following aspects: tangibility, reliability, responsiveness, assurance, empathy, employment, and practicality. The specific segmentation criteria are in "Table I":

TABLE I. Model of Educational Service Quality

\begin{tabular}{|c|c|c|}
\hline variable & Connotation & segmentation criteria \\
\hline \multirow[t]{7}{*}{ Tangiblility } & \multirow{7}{*}{$\begin{array}{l}\text { The external image of the school, such as } \\
\text { appearance, popularity, and teaching } \\
\text { facilities, etc. }\end{array}$} & Campus Environment \\
\hline & & software and hardware resources of the library \\
\hline & & perfection of teaching experiment \\
\hline & & Logistics services and related writings \\
\hline & & visibility of the school at the current level \\
\hline & & Culture life in school \\
\hline & & Academic environment \\
\hline \multirow[t]{3}{*}{ Reliability } & \multirow{3}{*}{$\begin{array}{l}\text { Whether the teaching services that the } \\
\text { school promises are reliable. }\end{array}$} & Complete the teaching tasks in time \\
\hline & & Provide students with the expected help \\
\hline & & Campus security \\
\hline \multirow[t]{3}{*}{ Responsiveness } & \multirow{3}{*}{$\begin{array}{l}\text { Whether the school can respond to the } \\
\text { needs of students in a timely manner. }\end{array}$} & Whether teachers can timely respond to students' learning needs \\
\hline & & Managers can handle student matters in a timely manner \\
\hline & & The provision status of immediate service by School \\
\hline \multirow[t]{4}{*}{ Assurance } & \multirow{4}{*}{$\begin{array}{l}\text { The ability of the school to provide services } \\
\text { to students }\end{array}$} & Whether teachers' evaluation of students' learning is objective \\
\hline & & Teacher's teaching ability \\
\hline & & Manager's ability in dealing with affairs \\
\hline & & Rationality of school management system \\
\hline \multirow[t]{4}{*}{ Empathy } & \multirow{4}{*}{$\begin{array}{l}\text { The school's emotional attitude towards } \\
\text { students }\end{array}$} & The degree of humanistic care for individual students \\
\hline & & Principles of dealing with affairs of different departments in school \\
\hline & & Teacher's attitude towards students \\
\hline & & The school provides students with subjective development space \\
\hline \multirow[t]{4}{*}{ Employment } & \multirow{4}{*}{$\begin{array}{l}\text { Whether the school can provide students } \\
\text { with help in employment }\end{array}$} & Whether sufficient employment information is provided \\
\hline & & $\begin{array}{l}\text { The relationship between the setting of school curriculum and } \\
\text { student employment }\end{array}$ \\
\hline & & Employment after graduation \\
\hline & & Employer's evaluation of school students \\
\hline \multirow[t]{3}{*}{ Practicality } & \multirow{3}{*}{$\begin{array}{l}\text { The school's training of students' } \\
\text { comprehensive ability in many aspects }\end{array}$} & The implementation status and quality of clubs in school \\
\hline & & The cultivation of students' practical ability \\
\hline & & School's attitude towards students' practical ability \\
\hline
\end{tabular}


2) Measurement method: After the model is established, the design of measurement method is the second step. The measurement method of this study is to divide the model variables into five grades. The grades include: first grade excellent, second grade - good, third grade - general, fourth grade - bad, fifth grade - poor. These five grades reflect the construction status of the school in segmentation variable above.

3) Questionnaire design: After setting up a model for educational service quality, research needs to understand the different aspects of the school. Therefore, this study used a questionnaire method. Before the questionnaire is launched, the study needs to design a corresponding questionnaire. The design of the questionnaire has a very large impact on the research situation, so the relevant personnel can't ignore it. The method of the questionnaire survey in this study is: First, letting the investigator conduct a five-grade evaluation of the segmentation variables in the above. Second, setting up some problems related to the segmentation variables to get the auxiliary information, and setting the related problems can make the research closer to the real state to some extent. For example, in the design of "employment" questions, this study used the question: "The number of times you get effective employment information on the school employment platform".

4) Sampling design: After the questionnaire is determined, the study ascertains the respondents. The subjects of this study are students from three universities in Xi'an. Students cover different grades, genders, and majors. The number of people selected for sampling is 300 per school. After 900 questionnaires were distributed, the number of questionnaires collected was 864, and the questionnaire recovery rate was $96 \%$.

\section{ANALYSIS OF THE QUESTIONNAIRE OF EDUCATION} SERVICE QUALITY IN PRIVATE COLLEGES AND UNIVERSITIES IN XI'AN

\section{A. Descriptive Statistics Analysis}

Through the recycling analysis of the questionnaire, it was found that the average score of the 28 indicators in the questionnaire was 5.6 points. But at the same time, the perceived value of the 28 indicators is only 4.7. Among them, tangibility accounted for $24.73 \%$, reliability accounted for $20.03 \%$, and others were below $20 \%$. This fully illustrates the importance of tangibility. In so many categories, the gap of "assurance" is the largest.

In addition, some students have proposed the problems in the development of the school, their own suggestions for the school, and expectations for the development of the school, including the following aspects:

\section{B. Reliability and Validity Analysis}

After obtaining the relevant survey results, the research needs to analyze the reliability and validity of the survey. The information reflected in the reliability of the survey is the reliability, stability and consistency of the survey. The reliability analysis method used in this study is Cronbach's $\alpha$. The result of the reliability analysis is 0.54 . Since the reliability of the Cronbach's $\alpha$ method shows good reliability within $0.4-0.75$, the study has good credibility. Validity is the detection of the degree of adaptation to the test object. When the validity is higher, it means that the test object reflects better real characteristics.

\section{One-way Analysis of Variance}

It is very important to make one-way ANOVA on the results of the study. One-way ANOVA reflects the effects of different control variables on the results. This study conducted the same test for overall compliance variance at different levels. The conclusion of significance $>$ significant level (0.05) was obtained through the test. Then, the statistical variables were tested and it is found that the single factor had less influence on the statistics.

\section{Verification Results}

After establishing the education service quality model and doing a relevant questionnaire survey, the research needs to use the Pearson correlation coefficient to analyze the validity of the model variables. In the analysis process by using Pearson correlation coefficient, if the significance level is $<0.01$, it indicates that there is a strong correlation between the dependent variable and variable. When the Pearson coefficient is $>0.8$, there is a strong positive correlation between the dependent variable and the variable. When the Pearson coefficient is $>0.6$, there is a positive correlation between the dependent variable and the variable. When the absolute value of the Pearson coefficient is $<0.3$, it means that there is only a weak linear correlation between the dependent variable and the variable.

Analysis of the survey results revealed a large difference between the student's expected value and the actual perceived value. Because of the large gap in "reliability," students' satisfaction in this area is very low.

\section{Problems in EdUCATIONAL SERVICES QUALity of PRIVATE COLLEGES AND UNIVERSITIES IN XI'AN AND THE SUGGESTIONS}

Through the above analysis, the author finds that there are still some problems in the service quality of private colleges and universities in $\mathrm{Xi}^{\prime}$ an. Then an incentive analysis of the problem is made and corresponding solutions are proposed.

\section{A. Main Problem}

In the above analysis, it is found that there is a large difference between the student's expected value and the actual perceived value. Because of the large gap in "reliability," students' satisfaction in this area is very low. Therefore, focusing on solving the problem of "reliability" has become a top priority. Through investigation and analysis, the author finds that the problem of school reliability mainly comes from the lack of sufficient attention to the educational services quality of colleges and 
universities. In addition to the poor student satisfaction, the lack of adequate attention to educational service quality in colleges and universities is the main reason why the education service quality of private colleges in Xi'an cannot meet the needs of the times. The main reasons for the lack of sufficient attention to the educational service quality of colleges and universities are: First, the relevant personnel do not have a relatively mature ideology. Second, there is no adequate attention to the efficient education service quality in the entire society. Third, the school has no good plans for building schools. Developing the educational service quality of colleges and universities is of great significance to the development of schools. To develop the quality of college education services requires the subjective practice of the school itself. Only when the school pays full attention to its own development can it better complete the relevant construction. However, according to the observation of the author, the three colleges are relatively vague on the issue of self-development.

\section{B. Relevant Suggestion}

In the face of problems, on the one hand, schools need to deal with urgent issues. The criterion for dealing with urgent problems is the gap between the expected value and the perceived value. At the same time, schools should also recognize that strengthening the emphasis on the educational service quality of colleges and universities is the best strategy for solving problems. In order to strengthen the school's emphasis on the quality of college education services, schools need to actively acquire outside information and do ideological construction of internal personnel.

\section{CONCLUSION}

In the measurement tool model for education service quality of college in Xi'an, the author made analysis of the variables such as school environment, teaching equipment, academic atmosphere, human environment, school logistics, school management, employment assistance provided by the school, affairs processing ability of school, and school practice teaching and so on, which is related to the model. Lack of sufficient attention is a problem in the service quality of colleges and universities. Therefore, it is necessary to strengthen the ideological construction of colleges and universities and actively establish the connection between universities and the outside world.

\section{REFERENCES}

[1] Pang Yulan, Wang Xin. An Analysis of the Factors Affecting the Performance of Students in Private Universities - An Empirical Study Based on Econometrics[J]. Education Modernization, 2017(1): 56-60. 庞玉兰, 王欣. 民办大学学生成绩影响因素分析一一基于计 量经济学的实证研究[J]. 教育现代化, 2017(1):56-60.

[2] Song Yafeng, Ma Jun. Research Hotspots and Frontier Analysis of National Vocational Education in China - Based on the Measurement and Visualization of Co-occurrence of Related Literature Keywords in China Knowledge Network (CNKI) Database (1987-2016),[J]. Vocational and Technical Education, 2017 (34): 6368. 宋亚峰, 马君. 我国民族职业教育研究热点及前沿分析一一基 于中国知网(CNKI)数据库(1987-2016 年)收录相关文献关键词共 现的计量与可视化分析 [J]. 职业技术教育, 2017(34):63-68.
[3] Dai Shu, Lu Qingyao, Pan Li. Measurement and Analysis of the Scope Economy of Ordinary Private Colleges and Universities in Jiangsu Province[J]. Journal of Hunan Industry Polytechnic, 2017, 17(2): 27-30. 戴澍, 鲁庆尧, 潘丽. 江苏省普通民办高校范围经济的 计量与分析[J]. 湖南工业职业技术学院学报, 2017, 17(2):27-30.

[4] Dai Shu, Pan Li, Chen Xuan. Measurement and Analysis of Scale Economy in General Private Colleges and Universities in Jiangsu Province[J]. China Management Informationization, 2017(1): 138139. 戴澍, 潘丽, 陈璇. 江苏省普通民办高校规模经济的计量与分 析[J]. 中国管理信息化, 2017(1):138-139.

[5] Lei Chengbo, Que Mingkun. Analysis of Difficulties in the Development of Profit-making Private Colleges and Universities in China and Relevant Suggestions[J]. Education and Vocation, 2017(7). 雷承波, 阙明坤. 我国发展营利性民办高校若干难点分析及相关建 议[J]. 教育与职业, 2017(7). 